\title{
From Scandal to Monastic Penance: A Reconciliatory Manuscript from the Early Twelfth-Century Abbey of St. Laurent in Liège
}

\author{
Tuamke Snijders and Steven Vanderputten
}

An important element of monastic penance and conflict resolution was its repetitive, almost cyclical nature. The manuscripts that were used during these performances often proceed implicitly, which makes them difficult to contextualize and understand. This article considers a possible example of such "hidden" reconciliatory discourse in a manuscript that was produced for the congregation of St. Laurent in Liège around the turn of the eleventh century: Brussels, Royal Library 9361-9367. It examines the sin of pride in monastic dignitaries, discusses the best way to atone for it, and provides tools for the penitent to start living a more virtuous life in the future. The surviving evidence suggests that this manuscript was produced in reaction to the deeds of abbot Berenger, whose actions in 1095 were considered scandalous by contemporaries because he had led his monks into confusion and sin. The article shows how the combination of texts in this manuscript takes on a different meaning because of these politically charged circumstances, and argues that the St. Laurent manuscript was a discreet but methodical way to end the resulting estrangement between Berenger and his monks. In this interpretation, Brussels RL 9361-9367 is a rare and highly relevant testimony to the ways in which monks in the early twelfth century dealt with psychological and social tensions in the wake of an intra-group conflict.

$\mathrm{H}$ IGH medieval monks combined the concepts of linear time and cyclical time in their daily routine. The Bible described unique historical events within a linear narrative, yet monks continually remembered these events through various rites and sacraments. An important part of monastic life was thus inherently repetitive. Hugh of St. Victor observed that repetition was necessary to make monks understand the true meaning of their actions, as

This paper was written in the context of the research network "Conventus" and the research project "Monastic leadership in the post-charismatic age," both of which are sponsored by the Research Foundation-Flanders (FWO). Our thanks to Melissa Provijn, Frederik Buylaert, and Maarten Prot for commenting on the draft version. Frequently used abbreviations: BM for Bibliothèque municipale; BNF for Bibliothèque Nationale de France; and RL for Royal Library.

Tjamke Snijders is Postdoctoral Fellow of the Research Foundation-Flanders (FWO) of Medieval History at Ghent University.

Steven Vanderputten is Professor of the History of the Early and Central Middle Ages at Ghent University. 
"man's erring flesh, which is the very principle of blind desire, cannot grasp the virtues that lie in perceptible things in a single moment, or even in a single continuous activity." $\mathrm{He}$ argued that a man could only learn to recognize truth, realize virtue, and attain a correct disposition through continual training. This training might take several forms: a monk could engage in silent prayer, or he could join his fellow monks to recite prose texts or sing the Lord's praise. ${ }^{2}$

Ideally, a monk who committed an error in his training would be promptly corrected. According to most consuetudines, this correction had to start with a formal accusation. ${ }^{3}$ The sinner either accused himself through confession, or he was accused during a chapter meeting by the abbot, the prior, or another monk. The ideal sinner would accept this accusation as valid and willingly undergo some kind of penance. This penance aimed for two things. First, the reprobate had to be reconciled to God's law to save his soul, and second, he had to be re-integrated into the immaculate monastic community. ${ }^{4}$ The penance had to be well thought-out to be able to achieve both functions. It was supposed to be related to the sin that had been committed: a proud monk had to humiliate himself, a runaway monk was banished to the abbey's hospital or poor house to underline his status as a "stranger," and so forth. ${ }^{5}$ Furthermore, the penance also needed to be repetitive in nature, so that the sinner would be able to grasp the spiritual meaning of his ordeal. A short-term punishment such as a beating would therefore be combined with a long-term ritual. This way, the penance could function as a training exercise that helped the sinner and his community back onto the path toward virtue.

Contemporary observers described these two elements to monastic penance in varying levels of detail. First and foremost, high medieval chroniclers eagerly seized upon the moment of accusation, because it entailed the dramatic possibilities of a public allegation, possible denial, conflict, and reconciliation. These moments provided the chroniclers with suspense-laden material that was well suited to their discourse, because they could be presented as powerful

\footnotetext{
${ }^{1}$ Hugh of St. Victor, "De sacramentis Christianae fidei," Patrologia Latina 176 (Paris 1854) 319321 (I:9). Paraphrase by Talal Asad, "On Ritual and Discipline in Medieval Christian Monasticism," Economy and Society 16, no. 2 (1987), 183.

${ }^{2}$ Asad, "On Ritual," 159-203.

${ }^{3}$ Jörg Sonntag, Klosterleben im Spiegel des Zeichenhaften: Symbolisches Denken und Handeln hochmittelalterlicher Mönche zwischen Dauer und Wandel, Regel und Gewohnheit (Berlin: Lit, 2008), 395-396.

${ }^{4} \mathrm{~A}$ few examples of this fundamental duality can be found in Mayke de Jong, "Pollution, Penance and Sanctity: Ekkehard's Life of Iso of St Gall," in The Community, the Family and the Saint: Patterns of Power in Early Medieval Europe, eds. Joyce Hill and Mary Swan (Turnhout: Brepols, 1998), 145-158; Claudia Rapp, "Spiritual Guarantors at Penance, Baptism, and Ordination in the Late Antique East," in A New History of Penance, ed. Abigail Firey (Leiden, Netherlands: Brill, 2007) 121-148; Norman Tanner, The Ages of Faith: Popular Religion in Late Medieval England and Western Europe (London: I.B. Tauris, 2008), 179.

${ }^{5}$ Sonntag, Klosterleben, 402-442, esp. 424-427.
} 
turning points in the monastery's history that supported the continuous moral education of the monks. Conversely, there was not much to recommend the long-term element to monastic penance in the eyes of a chronicler. As it consisted of low-key practices, pious repetitiveness, willing obedience, and the continual exercise of virtue in the monks' daily cycle of chanting and reciting, it did not lend itself to a description in the linear narrative of a chronicle and was therefore explained in far less detail. This predilection for drama has to some extent skewed our understanding of the mechanics of penance and conflict resolution during the high medieval period.

In order to study the long-term nature of monastic penance, we therefore have to forego the chronicles, gestae and other linear narratives, and concentrate more on the liturgical texts themselves. Some of the monks' penitential chants and readings have indeed been preserved. However, their very nature predisposes these texts to proceed implicitly, working patiently towards virtue without overtly discussing the specific issues that lay at the root of their creation. As a result, scholars often find these sources and their functionality difficult to contextualize, let alone understand. Worse still, in a number of instances, the reconciliatory intentions of these documents are completely lost on historians.

This article will consider a possible example of such "forgotten" or "hidden" reconciliatory discourse in a manuscript that was produced for the congregation of St. Laurent in Liège around the turn of the eleventh century: Brussels, Royal Library (henceforth RL) 9361-9367. It examines the sin of pride in monastic dignitaries, discusses the best way to atone for it, and provides tools for the penitent to start living a more virtuous life in the future. We will investigate the possibility that this manuscript was produced in reaction to the deeds of abbot Berenger, whose actions in 1095 were considered scandalous by contemporaries because he had led his monks into confusion and - according to some-into grave sin. We will argue that the St. Laurent manuscript was a discreet but methodical way to end the resulting estrangement between Berenger and his monks. In this interpretation, Brussels RL 9361-9367 is a rare and highly relevant testimony to the ways in which monks in the early twelfth century dealt with psychological and social tensions in the wake of an intra-group conflict.

\section{A CURIOUS MANUSCRIPT FROM THE ABBEY OF ST. LAURENT IN LIÈGE}

To this day, Brussels RL 9361-9367 has almost completely escaped scholarly attention, so that a short description of its contents is required. ${ }^{6}$ The manuscript

\footnotetext{
${ }^{6}$ The manuscript is not included in Van den Gheyn, Catalogue des Manuscrits de la Bibliothèque Royale de Belgique (Brussels: Lamertin, 1901-1948) or the monastery's extant booklists (Corpus
} 
consists of two codicological units, the first of which is devoted to Gregory of Tours's History of the Franks. This unit contains a twelfth-century colophon, which places the manuscript in St. Laurent, as well as an eighteenth-century shelf mark (LL 3-1) from the same library. The second unit was written around the end of the eleventh century by a different scribe. Although this second unit lacks a contemporary colophon, we can be sure that it was written for St. Laurent because its scribe had earlier written a chapter book for the same community. ${ }^{7}$ As this unit has its own eighteenth-century shelf mark (LL 3-2), it is clear that the two units were not bound together until after they were marked. ${ }^{8}$ The second codicological unit of Brussels RL 9361-9367 thus seems to have functioned as a separate manuscript.

We will concentrate exclusively on this second codicological unit, which we will designate Brussels RL 9361-9367 (II). It opens with two excerpts from the Synonyma by Isidore of Seville, which is a combination of a grammatical manual and a penitential guide. Next is De conflictu by Ambrose Autpert, which stages a dialogue between personifications of the vices and virtues. Then follow four rather divergent saints' lives. The story of Mary of Egypt, the holy harlot, is followed by the tale of Theophilus, who sold his soul to the devil to become a subdeacon. Saint Euphrosyna is known for entering into the monastic profession dressed as a monk; and Paula famously accompanied Jerome on his travels in the Holy Land (see Table 1). The compilation of Brussels RL 9361-9367 (II) is unusual. According to the Bollandists, who aspire to exhaustivity in their listing of hagiographical manuscripts from the Western Middle Ages, it contains a virtually unique combination of saints: there is only one other codex that contains the story of Theophilus as well as the Lives of Mary of Egypt, Euphrosyna, and Paula. ${ }^{9}$ The Brussels codex is even more unusual because St. Laurent already possessed a copy of De conflictu from the first half of the eleventh century and produced a second copy of the Synonyma between 1092 and

catalogorum Belgii: The Medieval Booklists of the Southern Low Countries, vol. 2: Provinces of Liège, Luxemburg and Namur, ed. Albert Derolez, Benjamin Victor, and Lucien Reynhout [Brussels: Paleis der Academiën, 1994], 111-125).

${ }^{7}$ Brussels RL 9361-9367 (II) is dated in the early or mid-eleventh century by Hubert Silvestre, "Notes sur les manuscrits de Bruxelles du De conflictu vitiorum atque virtutum d'Ambroise Autpert," in Calames et Cahiers: Mélanges de codicologie et de paléographie offerts à Léon Gilissen, ed. J. Lemaire and É. Van Balberghe (Brussels: Centre d'étude des manuscrits, 1985), 165 and to 1076-1100 by the Bollandists (Bibliotheca Hagiographica Latina Manuscripta: Index analytique des Catalogues de manuscrits hagiographiques latins publiés par les Bollandistes [BHLms], http://bhlms.fltr.ucl.ac.be/). The script is similar to that of St. Laurent manuscripts produced around the late eleventh century.

${ }^{8}$ Corpus, 2:108; Silvestre, "Notes," $165 \mathrm{n} 25$.

${ }^{9}$ Douai, BM, 871 (Anchin, first half of the twelfth century). 
Table 1. The contents of Brussels, Royal Library, 9361-9367

\begin{tabular}{lcl}
\hline Codicological unit & \multicolumn{1}{c}{ Folios } & \multicolumn{1}{c}{ Text } \\
\hline I & $1 \mathrm{r}-88 \mathrm{v}$ & The History of the Franks by Gregory of Tours \\
II & $89 \mathrm{r}-90 \mathrm{r}$ & The Synonyma by Isidore of Seville (book I, excerpt) \\
II & $90 \mathrm{r}-90 \mathrm{v}$ & The Synonyma by Isidore of Seville (book II, excerpt) \\
II & $90 \mathrm{v}-96 \mathrm{v}$ & De conflictu by Ambrose Autpert (the long version) \\
II & $96 \mathrm{v}-102 \mathrm{v}$ & The Life of St Mary of Egypt (BHL 5415) \\
II & $102 \mathrm{v}-105 \mathrm{v}$ & The story of Theophilus (BHL 8121) \\
II & $105 \mathrm{v}-108 \mathrm{r}$ & The Life of St Euphrosyna (BHL 2723) \\
II & $108 \mathrm{v}-110 \mathrm{v}$ & The Life of St Paula (BHL 6548) \\
\hline
\end{tabular}

${ }^{1}$ For the BHL numbers, see Bibliotheca hagiographica latina antiquae et mediae aetatis (Brussels 1898-1901); and Henryk Fros, Bibliotheca hagiographica latina antiquae et mediae aetatis: Novum supplementum (Brussels 1986).

1095. ${ }^{10}$ This is remarkable because earlier research into hagiographical manuscripts has shown that it was quite uncommon for the abbey of St. Laurent to acquire a text of which they already possessed a copy. ${ }^{11}$

Why did the monastery of St. Laurent create a manuscript that fit so uneasily into the collection of codices they already possessed? Of course, its production may have resulted from the personal preferences of its scribe. (For the sake of brevity, we will here continue to use the word "scribe" to indicate both the actual writer of the codex and the hypothetical compiler(s) who may have hovered in the background, although it was not unusual for the man who conceptualized a codex to ask someone else to actually write it. ${ }^{12}$ ) Yet an indepth study of the texts in Brussels RL 9361-9367 (II) on the following pages suggests that he probably had a far more pressing reason to produce this particular codex. As we will see, the texts share three themes that are closely related to monastic conflict and its resolution, namely, the sins that

\footnotetext{
${ }^{10}$ De conflictu is partially preserved in Brussels RL 8344-46 and Brussels RL 20716-19 (Silvestre, "Notes," 162-163 and 165-166). Isidore's Synonyma is preserved in Brussels RL 9875-80, which was produced between 1092 and 1095, according to Marie-Rose Lapière, La lettre orneé dans les manuscrits mosans d'origine bénédictine (XI-XII siècles) (Paris: Société d'éditions Les Belles lettres, 1981), 125.

${ }^{11}$ Tjamke Snijders, "Rewriting Hagiography in High Medieval Monasteries: Towards a Quantitative Approach," in Between Stability and Transformation: Textual Traditions in the Medieval Netherlands, eds. Youri Desplenter, Renée Gabriël, and Johan Oosterman (Ghent: forthcoming, 2013).

${ }^{12}$ Richard Gameson, “'Signed' Manuscripts from Early Romanesque Flanders: Saint-Bertin and Saint-Vaast," in Pen in Hand: Medieval Scribal Portraits, Colophons and Tools, ed. Michael Gullick (Walkern, U.K.: Red Gull Press, 2006), 69; Pamela Gehrke, Saints and Scribes: Medieval Hagiography in its Manuscript Context (Berkeley: University of California Press, 1993), 3 .
} 
come with power, the power of penitence to absolve these sins, and the kind of lifestyle that must follow the penitence.

\section{The Synonyma In Brussels RL 9361-9367 (II)}

The codex starts with fragments from the Synonyma by Isidore of Seville, a text that shows how synonyms can be used as a stylistic tool. ${ }^{13}$ Modeling his work on both classical texts and the penitential psalms, ${ }^{14}$ Isidore crafted a dialogue between a sinful but penitent Soul and a personification of Reason who counsels the Soul to seek forgiveness and strive for better conduct in the future. ${ }^{15}$ In the course of the dialogue, the Soul evolves from a state of humble contrition to a renewed spiritual confidence through a confession of his guilt. ${ }^{16}$ As a result, the Synonyma became popular as a source for penitential discourse in the Middle Ages, and it was not uncommon for scribes to choose their own selections from the work based on the particular demands of their situation. ${ }^{17}$ The scribe of Brussels RL 9361-9367 (II) made a fairly narrow selection, using just one-sixth of Isidore's text (namely, chapters 56 to 77 from the first book and chapters 87 to 96 from the second book) and opens the codex with an explicit demand for penitence:

May God reward your wishes, o Soul. May God favor your prayers, may God make you master of your wishes, may God bring about your desire for good, may God strengthen your vow, may God favor your vow, may everything you do be supported by God. Come, then, while we may, while fate is far away. Pray, beg, entreat! Do not be silent, burst out in speech, exclaim forcefully! Bewail your iniquities, deplore the wickedness of your sins. Annihilate what was wickedly done with tears. Wash away

\footnotetext{
${ }^{13}$ Isidori Hispalensis Episcopi Synonyma. Corpus Christianorum Series Latina 111b, ed. Jacques Elfassi (Turnhout: Brepols, 2009).

${ }^{14}$ Jacques Fontaine, "Isidore de Séville auteur 'ascétique': Les énigmes des Synonyma," Studi medievali ser. 3, vol. 6, no. 1 (1965): 173-184; idem, "Pénitence publique et conversion personelle: l'apport d'Isidore de Séville à l'évolution médiévale de la pénitence," Revue de droit canonique 28 (1978): 151-152.

${ }^{15}$ The dialogue is between "Ratio" and "Anima," often translated as "Reason" and "Man." Yet the scribe from Brussels RL 9361-9367 (II) clearly intended "Anima" to be understood as "Soul," because he corrected himself when he mislabeled "Anima" as "Homo" on fol. 90r.

${ }^{16}$ Fontaine, "Isidore de Séville," 170-173.

${ }^{17}$ Claudia Di Sciacca, Finding the Right Words: Isidore's "Synonyma" in Anglo-Saxon England (Toronto: University of Toronto Press, 2008), 18-20, 34-35, and 174 notes that it was unusual for such compilations to be copied and to acquire a "tradition." See also Jacques Elfassi, "Les deux recensions des Synonyma," in L'édition critique des oeuvres d'Isidore de Séville: Les recensions multiples. Actes du colloque organisé à la Casa de Velázquez et à l'Université Rey Juan Carlos de Madrid (14-15 janvier 2002), eds. A. Andrés Sanz, J. Elfassi, and J. C. Martín (Paris: Institut d'Études Augustiniennes, 2008), 153-184; and Isidore of Seville, Synonyma, xxiii-lviii.
} 
with tears what was unlawfully committed. Crimes are wont to be washed away by lamenting. ${ }^{18}$

These lines, which are taken from chapter 56 of the Synonyma's first book, are a very compelling way to open the codex because they are taken out of context. As a result, the manuscript's audience could not relate them to the sins that the protagonist from the Synonyma had admitted to in previous chapters. For St. Laurent's monks, these opening lines did not entreat Isidore's protagonist to penitence but were aimed at themselves, admonishing them to confess their sins, bewail them publicly, and cry a river of tears over them.

In the rest of the text, Isidore's sinner obediently laments his sins and admits his guilt. He requests prayers on his behalf, begs for God to listen to his prayers and be merciful, and implores Him to extinguish the flame of worldly desire that still burns within him. ${ }^{19}$ Because of this exemplary penitence, Reason forgives him, on the condition that he will, in effect, mend his ways. The scribe then skips over chapters 1 to 86 from the second book, which counsels the Soul on how to achieve a more virtuous life. He was only interested in one seemingly minor point from the Synonyma's second book: the necessity to remain humble and uninterested in worldly glory if one is elevated to the highest office. This point is discussed in chapters 87 to 96 , a passage of about 600 words. It starts by emphasizing the need for humility in office. The text warns further that those who cannot hold an office without sinning should avoid holding it in the first place. In fact, nobody can administer earthly things without sinning, especially if money is concerned, and higher offices are especially dangerous in this respect because they engender envy. ${ }^{20}$ "It is difficult," states Isidore, "to serve these responsibilities to heavenly and earthly things at the same time, both cannot be cared for at the same time." ${ }^{21}$ This problem was well known among monastic officials, as the abbot and prior were constantly attempting to manage their monastery's temporal assets together with its spiritual ones. The St. Laurent scribe fully endorses Isidore's solution to this office-holding dilemma, which is to try to remain humble, spurning everything that is valued by the world.

The selection from the Synonyma in Brussels RL 9361-9367 (II) thus starts with a strong demand for penitence, and in the second part provides the context for this demand by focusing on the condition of the sinner, who was almost

\footnotetext{
${ }^{18}$ Brussels RL 9361-9367 (II), fol. 89r; see Isidore of Seville, Synonyma, 45-46 (ch. 1:56).

${ }^{19}$ Brussels RL 9361-9367 (II), fols. 89v-90r; see Isidore of Seville, Synonyma, 53, 55, 56-57, 59 (ch. 1:67, 1:69, 1:71 and 1:72).

${ }^{20}$ Brussels RL 9361-9367 (II), fol. 90v; see Isidore of Seville, Synonyma, 134-137, 139 (ch. 2:87-88, 2:90, 2:93).

${ }^{21}$ Brussels RL 9361-9367 (II), fol. 90v; see Isidore of Seville, Synonyma, 140 (ch. 2:94).
} 
involuntarily pushed into pride and envy by his high office. It implies that the need for penitence is most crucial for leaders, who stand in the limelight because of the high offices they hold and who have sinned because of them. Through proper penitence their sins may be forgiven, but they are counseled to remain humble if they want to avoid a relapse.

\section{De Conflictu Vitiorum et ViRTUtum in Brussels}

$$
\text { RL 9361-9367 (II) }
$$

The second text in Brussels RL 9361-9367 (II) is dedicated to the theme of fending off temptations in order to remain humble and virtuous. It consists of a dialogue between the vices and virtues known as De conflictu vitiorum et virtutum, which is ascribed to Ambrose Autpert. ${ }^{22}$ Again, this text opens with a strong sentiment: "All who desire to live a godly life in Christ Jesus will be persecuted" (II Tim. 3:12). Instead of taking this literally, Ambrose embarks on a tropological interpretation of the quotation. His text deals with the vices that "persecute" men, and the virtues that can save them. The most dangerous vice of all, because all other sins flow from it, is that of pride. ${ }^{23}$ Ambrose makes Pride flatter the protagonist, saying that he is certainly more capable than almost everyone else. True Humility, Pride's enemy, responds that if the protagonist does not humble himself to the extent of his greatness, he will lose himself entirely. ${ }^{24}$ Next, the vices of Cupidity, Hardheartedness, Theft, and Fraud argue that a man who is driven to them because of some dire need does not commit a sin, an argument that is refuted by Contempt for the World, Mercy, and Innocence. In this manner, Ambrose contrasts the temptations of twenty-five vices to the counter-arguments made by their opposing virtues, providing monks with a practical defense against the most common lures of monastic life.

The last paragraphs of De conflictu take the instructions for a virtuous life one step further by discussing whether it is necessary to go into exile in order to be truly free of persecutions and thus to lead a truly virtuous life. The Bible seems to suggest this in Matt. 13:57 ("No prophet is accepted in his native land"). However, Ambrose himself strongly rejects this point of view. One has only to look at the saints, he argues, to realize its inaccuracy, for Paul and Anthony from Thebes were perfect among the Thebans,

\footnotetext{
${ }^{22}$ Ambrosius Autpertus, Libellus de conflictu vitiorum atque virtutum, ed. R. Weber, Ambrosius Autpertus, Opera III. Corpus Christianorum Continuatio Mediaevalis 27b (Turnhout: Brepols, 1979), 909-931. Over the years, the dialogue has also been ascribed to various other authors. See Silvestre, "Notes," 161.

${ }^{23}$ This is a common medieval thought, stemming from Ecclesiasticus/Sirach 10:13 (sometimes 10:15): "Quoniam initium omnis peccati est superbia."

${ }^{24}$ Brussels RL 9361-9367 (II), fol. 91r; see Ambrosius Autpertus, De conflictu, 910 (ch. 2).
} 
Hilarion from Palestine was perfect among the Palestinians, and so forth. "Can it possibly be," he asks rhetorically, "that only the monastic life in your province is exempt from this rule, so that your order has no monks from its immediate surroundings, but only monks from outside the region?" As the answer is clearly negative, he finally states, that "I do not say these things because I regard with the highest praise those who leave one kingdom for another, the public for the hermitic life; but to show that those who leave their native country in sentiment rather than with their feet are also happy and perfect. I therefore entreat those who deny that such things could happen to you, to consider with alert zeal why God did not say: "No prophet is perfect [perfectus est] in his native land," but that "No prophet is accepted [acceptus est] in his native land." 25

In short, Brussels RL 9361-9367 (II) starts by highlighting the need for sinning leaders to perform penitence and remain humble to avoid a relapse, and continues with practical guidelines on how one achieves such humility and virtuousness in the face of constant temptation in one's own monastery. Ambrose Autpert teaches that moral perfection in a monastic environment is indeed possible, if one uses the arguments he ascribes to the virtues to stave off the whispering voices of Pride and its daughters. Thus far, the texts in Brussels RL 9361-9367 (II) convey a coherent message.

\section{The Saints’ Lives in Brussels RL 9361-9367 (II)}

The codex continues with four saints' lives that illustrate Ambrose Autpert's point that perfection can be achieved by anyone anywhere. Instead of using Paul, Anthony, and Hilarion as examples, the scribe chose Euphrosyna, Paula, Mary of Egypt, and Theophilus. The details of their Lives are dramatically different, as we are dealing with a cross-dressing virgin, a rich and venerable widow, a shameless harlot, and a man who sold his soul to the devil out of unmitigated ambition. Nevertheless, the basic structure of these stories is very similar. They are all examples of the kind of hagiography that contrasts a former life of riches and/or sin with a present state of humility and spiritual devotion. As if reacting to Ambrose's discussion of exile, the three women all choose to separate themselves from their former lives in order to gain perfection, whereas the only man in Brussels RL 9361-9367 (II) is able to achieve perfection at home through a forty-day penance.

The Life of Euphrosyna is the most straightforward tale of the four. ${ }^{26}$ This rich and virtuous virgin secretly fled to a monastery dressed as a monk

\footnotetext{
${ }^{25}$ Brussels RL 9361-9367 (II), fol. 96r-v; Ambrosius Autpertus, De conflictu, 929-930 (ch. 28).

${ }^{26}$ Life of Euphrosina, ed. AASS Jan. 2 (Antwerp 1643), 712-722.
} 
rather than submit to the advantageous marriage her father had arranged for her. Her exile consisted of a life spent in her monastic cell, which she could not leave because her beauty disturbed the monks. She also cut herself off from her grieving father, to whom she did not identify herself until the moment of her death. In doing so, Euphrosyna exemplified the ideal of being dead to the world and to her loved ones.

The venerable widow Paula also abandoned her considerable riches, her home, and her children to gain perfection in exile. ${ }^{27}$ After an episcopal court forced her friend Jerome to leave Rome after having been convicted of clerical misconduct, Paula abandoned Rome and "her palace glittering with gold" to accompany him and "dwell in a mud cabin." 28 Jerome, who served as her biographer, greatly emphasized her humility, for "by her lowliness she surpassed all others in virtue and influence and, while she was least among all, was greater than all." He sketched her as a contemporary Abraham who was called away from her home country by God. ${ }^{29}$

Mary of Egypt differs from the other women in that she was a notorious sinner. ${ }^{30}$ A woman with an insatiable sexual appetite, she lay with men for sheer pleasure. Finally realizing the error of her ways, she fled to the desert, where she lived a life of extreme solitude, deprivation, and hardship. Because of this penitence, she was forgiven for her sins and became a saint. She told her life story to a monk who was clearly a less perfect ascetic than she, thereby underlining the value of exile in the desert over the comforts of cenobitic life. Even more importantly, her dramatic repentance-which spoke to men as well as to women - underlined that penitence and a subsequent life of virtue could erase any misdeeds, no matter how grave. ${ }^{31}$

Theophilus the subdeacon was the only male saint in the codex. ${ }^{32} \mathrm{He}$ was elected unanimously as a bishop, but refused his promotion out of humility. However, when the new bishop removed him from his position as subdeacon without good reason, he became filled with a desire to regain his post. With the help of a Jewish magician, he negotiated a pact with the devil and sold his soul in exchange for his old position. One day later, the bishop reinstated

\footnotetext{
${ }^{27}$ Life of Paula, Corpus Scriptorum Ecclesiasticorum Latinorum LV: S. Eusebii Hieronymi opera - epistulae LXXI-CXX, ed. Isidorus Hilberg (Vienna and Leipzig 1922), 306-351 (letter 108).

${ }^{28}$ Ibid., 306 (ch. 1).

${ }^{29}$ Ibid., 309 (ch. 3); Paula's Abraham-like exile is discussed in Andrew Cain, "Jerome's Epitaphium Paulae: Hagiography, Pilgrimage, and the Cult of Saint Paula," Journal of Early Christian Studies 18, vol. 1 (2010): 105-139, esp. 120.

${ }^{30}$ Life of Mary of Egypt, ed. AASS Apr. I (Antwerp 1675), 76-83.

${ }^{31}$ Ruth Mazo Karras, "Holy Harlots: Prostitute Saints in Medieval Legend," Journal of the History of Sexuality 1, no. 1 (1970), 3, 7, 30-32.

${ }^{32}$ Life of Theophilus by Paulus Diaconus, ed. AASS Feb. 1 (Antwerp 1658), 483-484. See Albert Gier, Der Sünder als Beispiel: Zu Gestalt und Funktion hagiographischer Gebrauchstexte anhand der Theophiluslegende (Frankfurt am Main: P. Lang, 1977), 208-209, 333-335.
} 
Theophilus as subdeacon. At that moment, Theophilus realized that he had sinned and was overcome with remorse. He fasted and prayed to the Virgin Mary for forty days in an exemplary manner. Because of his penitence, Mary absolved him from his contract. Theophilus then sped to the bishop, who was in the act of reading Mass, and conducted a public penitence by telling the bishop and all present about his misdeeds. The contract was read to the assembled public, whereupon the bishop cried out that all should come and see how efficient Theophilus's penitence had been, and how his tears had washed away his sins. ${ }^{33}$ Forgiven, the penitent sinner died on the spot, his body showing unmistakable signs of holiness. This story would become one of the most popular Marian miracles. ${ }^{34}$ As such, it was often read from a Marian point of view, with the Virgin's victory over the demonic Jew as the story's focal point. In an early twelfth-century manuscript from Anchin, for example, the story of Theophilus was entitled "Miracle of St Mary, concerning Theophilus the Penitent." 35 Alternatively, the story could be read from Theophilus's point of view by focusing on the dangers of undue ambition. ${ }^{36}$ This is the approach taken in Brussels RL 9361-9367 (II), which incorporated the story under the heading "The tale of a certain subdeacon" (Narratio de quodam vice domino). Strikingly, this title does not name the Virgin Mary or even Theophilus himself, but directs the reader's attention to the office that the protagonist wanted to regain. In presenting the story like this, the scribe emphasized that the vices of pride and worldly ambition had led Theophilus to a spiritual downfall that cost him his soul, which he only regained through an intense, long-term and partially public penance.

Taken together, the compiled texts in Brussels RL 9361-9367 (II) explore the vices of monastic life together with their antidotes. Its opening sentences seem to speak directly to the monastic community of St. Laurent, urging the monks to confess their sins and tearfully repent. That does not imply that the codex was meant as a literal indictment of sins that the congregation had committed - the St. Laurent monks were unlikely to have needed to atone for a life of shameless whoring. Instead, the manuscript functioned as a

\footnotetext{
${ }^{33}$ Brussels RL 9361-9367 (II), fol. 105r; Life of Theophilus, 486 (ch. 15-16).

${ }^{34}$ Gier, Der Sünder als Beispiel, 344-347.

${ }^{35}$ Douai, BM, 871, fol. $155 \mathrm{v}$.

${ }^{36}$ Gier, Der Sünder als Beispiel, 255, 271, and 342. From the twelfth century onward, the focus would normally lie on the role of the Jew in corrupting Theophilus and the grace of Mary in saving him. A reading from the point of view of ambitio was more common in the preceding centuries and never disappeared completely. See Pamela Anne Patton, "Constructing the Inimical Jew in the Cantigas de Santa Maria: Theophilus's Magician in Text and Image," Beyond the Yellow Badge: Anti-Judaism and Antisemitism in Medieval and Early Modern Visual Culture, ed. Mitchell B. Merback (Leiden, Netherlands: Brill, 2008), 242-252; also Michael W. Cothren, "The Iconography of Theophilus Windows in the First Half of the Thirteenth Century," Speculum 59, no. 2 (1984), 308-341.
} 
moral guide that needed to be interpreted before it could be understood, indicting sins that were to the monks what whoring was to Mary of Egypt. At this slightly higher level of abstraction, the manuscript keeps returning to three themes throughout the various texts.

The first theme of Brussels RL 9361-9367 is a discussion of the vices that are intrinsic to high office. The Synonyma starts by warning that no earthly matters can be administrated without sinning. It emphasizes the great dangers of holding a high office and explains that the powerful are easily ambushed by envy. De conflictu continues the theme of vices that ambush men and directs the reader's attention to pride as the mother of all sins. This perspective is again taken up in Theophilus's story, which illustrates how pride and ambition in an officeholder led to a fatal series of decisions that cost the protagonist his soul.

The second theme explores how penance can absolve such sins. Two competing models of penance are presented without clearly valuing one above the other. The model that is proposed in the Synonyma, De conflictu, and the story of Theophilus revolves around an intense cycle of praying, crying, and fasting, of which a significant part must be publicly performed. This penance "at home" is presented as a difficult but effective way to absolve grave sins. Simultaneously, the last paragraphs of De conflictu ask whether exile is not the only effective penance in the long run. Although Ambrose Autpert answers this question in the negative, still the Lives of Euphrosyna, Mary of Egypt, and Paula all present exile as the most effective way to absolve sins-although it should be noted that the Life of Mary adds the caution that exile should stem from a heartfelt desire to be dead to the world, never from a desire to show off to one's monastic peers. ${ }^{37}$ Nevertheless, the advice on penance in these texts is contradictory, and the codex leaves the question of exile unresolved.

The third and last theme in Brussels RL 9361-9367 (II) is praise of humility, which is presented as the virtue that opposes pride and envy. Every sinner should exercise humility in the aftermath of penance in order to avoid a relapse into his or her former habits. The Synonyma explicitly warns that a sinner who returns to his former prideful ways invalidates his penance. This reasoning gained widespread popularity during the second half of the eleventh century, especially after 1080. In that year, Gregory VII proclaimed that Emperor Henry VII had failed to mend his ways after his Walk to Canossa. As a result, Henry's penance there was said to be false and Gregory once again excommunicated him. ${ }^{38}$ In order to help the audience of

\footnotetext{
${ }^{37}$ Life of Mary of Egypt, 77.

${ }^{38}$ Among the abundant literature, see Sarah Hamilton, "Penance in the Age of Gregorian Reform," Retribution, Repentance, and Reconciliation, eds. Kate Cooper and Jeremy Gregory (Woodbridge, U.K.: Ecclesiastical History Society and Boydell Press, 2004), 47-73, esp. 49-51.
} 
Brussels RL 9361-9367 (II) to avoid such a relapse, De conflictu provides practical guidelines for living virtuously and humbly, and the saints' lives offer examples of virtuous living through humility.

In short, Brussels RL 9361-9367 (II) intended to convey guidelines for longterm moral behavior to the community of St. Laurent. While this in itself is common enough, it is intriguing that these guidelines do not address the novices and lower monks of the community as much as its officeholders. These men are singled out as naturally beset by the sins of pride and ambition. The codex thus functions similarly to the high medieval penitential guides that advised priests to tailor their admonitions to the sinner's profession, warning a judge not to accept bribes, a trader not to oppress anyone, and so on. ${ }^{39}$ Here, officeholders are warned against pride. The question is whether there may have been a specific occasion for the monks of St. Laurent to produce a codex that was aimed at the sins and penance of officeholders, given that it contained two texts they already possessed. While the manuscript does not name a specific individual or circumstance that would explain its production, late eleventh-century St. Laurent did, in fact, witness a crisis that centered around the very themes that are discussed in Brussels RL 9361-9367 (II).

\section{Contextualizing the Manuscript}

Between the foundation of St. Laurent in 1026 and the mid-twelfth century, seven abbots led the community. Stephen, Lambert, Heribrand, Everard, and Wazelin had reasonably peaceful careers that seem unrelated to Brussels RL 9361-9367 (II). ${ }^{40}$ There remain two abbots, Wolbodon (1071-1077 and 1092-1095) and Berenger (1077-1092 and 1095-1116), who struggled for supremacy at the end of the eleventh century.

During these years, the Investiture Controversy was hitting the diocese of Liège relatively hard. This episcopal see formally belonged to the Holy Roman Empire, yet many of its monasteries harbored strong Gregorian sympathies. It could boast several famous schools and abbeys, making it a center of knowledge, education, and the spread of ideas-which were sometimes Gregorian in nature. In the late eleventh century, the emperor attempted to bring his troublesome diocese into line by nominating the vigorous Otbert (1091-1119) as the new prince-bishop of Liège. Otbert immediately started a campaign to replace all Gregorian abbots with Imperial

\footnotetext{
${ }^{39} \mathrm{~A}$ tenth-century example is the Romano-German pontifical discussed in ibid., 61.

${ }^{40}$ Ursmer Berlière, "Abbaye de Saint-Laurent à Liège," Monasticon Belge 2 (Maredsous 1928), 32-57; and idem, "L'abbaye de Saint-Laurent de Liège," Revue bénédictine 7 (1890), 13-26.
} 
sympathizers. He nominated new abbots for Florennes, ${ }^{41}$ St. Gérard de Brogne, ${ }^{42}$ and St. Trond $;{ }^{43}$ and exiled the abbot of St. Hubert. ${ }^{44}$ St. Laurent suffered through a similar situation, which is known primarily through a chronicle called the Cantatorium. ${ }^{45}$ This chronicle was written by an eyewitness, a monk called Lambert the Younger from the nearby monastery of St. Hubert, who finished his work around $1106 .{ }^{46}$ Lambert's Cantatorium gives a detailed account of the Investiture Controversy in the monasteries of St. Hubert and St. Laurent, which accords well with other available sources. It should be noted, however, that Lambert's sympathies are markedly Gregorian, and he presents Berenger in almost hagiographical terms while sketching Wolbodon as thoroughly heretical. ${ }^{47}$

Lambert the Younger relates how St. Laurent's problems started in 1077, when Wolbodon was deposed as abbot of St. Laurent because he was too proud of his position and his birth to display proper humility. He was asked to go into temporary exile to atone for his behavior but refused and fled to Hungary. ${ }^{48} \mathrm{He}$ was replaced with Berenger, the prior of the neighboring abbey of St. Hubert. In 1091, when the bishop of Liège died of old age and Emperor Henry IV designated Otbert as his successor, Wolbodon saw a chance to try to improve his situation. ${ }^{49}$ He supposedly paid a large sum of money to Otbert in exchange for a promise to reinstate him as the abbot of St. Laurent. ${ }^{50}$ In February 1092, Otbert ordered Berenger to step down.

\footnotetext{
${ }^{41}$ Ursmer Berlière, "Abbaye de Florennes," Monasticon Belge 1 (Maredsous: Abbaye de Marsedsous, 1890-1897), 8.

${ }^{42}$ Ursmer Berlière, "Abbaye de Saint-Gérard,” Monasticon Belge 1:31.

${ }^{43}$ Paulette Pieyns-Rigo, "Abbaye de Saint-Trond," Monasticon Belge 6 (Liège: Centre national de recherches d'histoire religieuse, 1976), 37-38.

${ }^{44}$ Andrée Despy-Meyer and P. P. Dupont, “Abbaye de Saint-Hubert," Monasticon Belge 5 (Liège: Centre national de recherches d'histoire religieuse, 1975), 37-38.

${ }^{45}$ Cantatorium, ed. Karl Hanquet, La chronique de Saint-Hubert dite Cantatorium (Brussels: Hayez, 1906). The translation by A. L. P. de Robaulx de Soumoy, Chronique de l'abbaye de St. Hubert dite Cantatorium (Brussels: Meline \& Cans, 1847; repr. Brussels: Editions Culture et Civilsation, 1982) used different chapter numbers from Hanquet and the edition in the MGH SS 8 (Hannover: Impensis bibliopolii Haniani, 1848), 565-630; we follow Hanquet's numbering.

${ }^{46}$ Karl Hanquet, "Introduction," Cantatorium, vi; idem, "L'auteur de la Chronique de SaintHubert, du second livre du Miracula Sancti Huberti et du Vita Theoderici. Réponse à M. Cauchie," Compte rendu des séances de la Commission Royale d'Histoire, ou: recueil de ses bulletins, ser. 5, vol. 11 (1901), 477-516.

${ }^{47}$ John van Engen, Rupert of Deutz (Berkeley: University of California Press, 1983), 25.

${ }^{48}$ Cantatorium, 88-89 (ch. 29).

${ }^{49}$ The episode is described in (among others) Alfred Cauchie, La querelle des investitures dans les diocèses de Liège et de Cambrai, vol. 2 (Louvain: C. Peeters, 1890), 7-8 and 45 onward; Van Engen, Rupert of Deutz, 27-30; Hubertus Seibert, Abtserhebungen zwischen Rechtsnorm und Rechtswirklichkeit: Formen der Nachfolgeregelung in lothringischen und schwäbischen Klöstern der Salierzeit (1024-1125) (Mainz, Germany: Selbstverlag der Gesellschaft für Mittelrheinische Kirchengeschichte, 1995), 350-377.

${ }^{50}$ Cantatorium, 154-166 (ch. 69-70). The monetary scenario is detailed in the Chronicon Sancti Laurentii, ed. Wilhelm Wattenbach, MGH SS 8 (Hannover: Impensis bibliopolii Hahiani, 1848),
} 
Berenger fled to St. Hubert with some of his monks. ${ }^{51}$ St. Hubert's abbot, Thierry II, warmly welcomed him and offered him the priory in Evergnicourt to live in. Evergnicourt was situated in the archdiocese of Reims, well outside the borders of Liège and Otbert's jurisdiction. ${ }^{52}$ Berenger settled there and over time his former monks joined him in exile. ${ }^{53}$

The exiled community prided itself on its moral purity and energetically defended its position, arguing that Otbert was a simoniacal bishop and therefore a heretic, that the sacraments he provided were invalid, and that contact with him must be avoided at any cost. ${ }^{54}$ As we will see, their radical point of view would become a crucial element in the production of Brussels RL 9361-9367 (II) in later years. It is exemplified in their refusal to come into contact with people who had been in contact with Otbert, as Thierry II found out to his dismay. This Gregorian abbot of St. Hubert had grown convinced of the truth of the exile's ideas and decided to go into voluntary exile himself, so that he would not have to deal with Otbert any longer and could preserve his spiritual purity. Yet Otbert reacted to Thierry's open defiance with military threats and the villagers of St. Hubert complained that Thierry had lost his mind and deserted his abbey. ${ }^{55}$ These threats and complaints upset Thierry to such an extent that he changed his mind. He traveled to Otbert in order to plead his case and presumably asked the bishop to reinstate him as the abbot of St. Hubert. However, Otbert had decided that it would be better to have a less troublesome abbot at the head of St. Hubert, and refused Thierry's request. He then travelled to his old friend Berenger, who was staying in Reims. Yet Berenger refused to talk to him because he had "polluted" himself through contact with a heretic. Berenger forbade Thierry to come into his presence and threatened that he would flee Evergnicourt with all his monks if Thierry tried to go there. Thierry was hurt, but nevertheless managed to convince Berenger that he was still worthy of his esteem. They reconciled and travelled together to

277; and its credibility is discussed in Cauchie, La querelle 1:9-16; and Van Engen, Rupert of Deutz, 28.

${ }^{51}$ Cantatorium, 157 (ch. 70).

${ }^{52}$ L. H. Cottineau, Répertoire topo-bibliographique des abbayes et prieurés (Maçon: Protat, 1939), 1087.

${ }^{53}$ The Cantatorium does not state clearly whether all of the monks eventually left St. Laurent, yet this is suggested in Rupert of Deutz, Carmina, ed. M. Wegener, MGH Libelli de lite imperatorum et pontificum 3 (Hannover: Impensis bibliopolii Hahniani, 1897), 622-641, here 636-637 (ch. 10). The fifteenth-century Chronicon at 278 reports that discord grew among the monks who stayed behind and that in the end they all left St. Laurent.

${ }^{54}$ Cantatorium, $157-159$ (ch. 70 ); see also Maria Lodovica Arduini, Non fabula sed res: Politische Dichtung und dramatische Gestalt in den Carmina Ruperts von Deutz (Rome: Edizioni di storia e letteratura, 1985), 101-108.

${ }^{55}$ Cantatorium, 158-161 (ch. 70). 
Evergnicourt, where the monks' first reaction proved to be very similar to Berenger's. They were scandalized by the idea that Thierry had come into contact with Otbert, and Thierry had to plead his case once again. The abbots managed to convince all but two of the monks that things had not occurred as they had been led to believe (non se rem sic habere). ${ }^{56}$

Berenger stayed in Evergnicourt for three more years, together with twentyfive monks from both St. Laurent and St. Hubert who gloried in their spiritual purity. ${ }^{57}$ Even so, Berenger was not content with his life as an exile and was working behind the scenes to be reinstated as abbot. One of his monks, Rupert of Deutz, was busy composing a Carmina that described the community's exile and suffering at the hands of Henry IV, who was portrayed as the Antichrist himself, with Bishop Otbert as his henchman. ${ }^{58}$ Such poems were recognized ways of interesting lay rulers in monastic problems and Berenger may have had plans for the text. ${ }^{59} \mathrm{He}$ certainly tried to gather as many powerful lords to his cause as he could, and won the support of people such as Duke Godfrey of Bouillon, Count Albert III of Namur, Count Arnulf I of Chiny, and possibly even Emperor Henry IV. ${ }^{60}$

About four months later, Bishop Otbert sent a letter to Berenger in which he offered to reinstate him as abbot of St. Laurent. ${ }^{61}$ According to the Cantatorium, Berenger hesitated to accept this offer, as he knew full well that he would be publicly blamed and accused of apostasy for doing so. ${ }^{62}$ After all, the exiles were convinced that Otbert's heresy was in a sense contagious. Describing Berenger's moment of hesitation, the St. Hubert chronicler conspicuously used the third person singular, indicating that Berenger vacillated and decided alone and without consulting his monks. The Cantatorium recounts how the abbot finally decided that Otbert's change of heart must have been God's will and could not be rejected. He journeyed back to Liège, taking some of his men with him. ${ }^{63}$ Without

\footnotetext{
${ }^{56}$ Ibid., $164-165$ (ch. 70).

${ }^{57}$ Ibid., 165 (ch. 70 ).
}

${ }^{58}$ Carmina, 622-641; see Arduini, Non Fabula, 39-74. The most comprehensive discussion of Rupert's work and career is in Van Engen, Rupert of Deutz.

${ }^{59}$ Cauchie, La querelle 1:65-66; and Steffen Patzold, Konflikte im Kloster: Studien zu Auseinandersetzungen in monastischen Gemeinschaften des ottonisch-salischen Reichs (Husum, Germany: Matthiesen, 2000), 73.

${ }^{60}$ Cantatorium, $186-187$ (ch. 77); a letter from Pope Urban II to Berenger warns him not to rely on the possibility of "H" (that is, Emperor Henry IV) taking care of things. See J.-P. Migne, PL 151 (Paris, 1849-1855), 395-397; Van Engen, Rupert of Deutz, 29; Seibert, Abtserhebungen, 282-290 and $355 \mathrm{n} 702$.

${ }^{61}$ Cantatorium, 194-197 (ch. 78); also Cauchie, La querelle 1:76-77.

${ }^{62}$ Cantatorium, $197-198$ (ch. 79). There are no contemporary sources from St. Laurent that describe Berenger's reaction and the subsequent events.

${ }^{63}$ Cantatorium, 198 (ch. 79): "assumens secum quosdam suorum properavit Leodium." "Quosdam suorum" probably refers to those who had earlier agreed to accompany Berenger to Otbert for a formal meeting (Cantatorium, 188-191 [ch. 77]). Alternatively, it could refer to 
consulting his retinue, Berenger then agreed to be reinstated as abbot on the condition that Otbert would return all St. Laurent's goods that had been alienated during his exile. ${ }^{64}$

Berenger's actions were not in accordance with established custom. Lambert the Younger contrasts Berenger's actions to those of Thierry II, who immediately summoned his monks for a consultation when he heard the news about Berenger's decision. ${ }^{65}$ In so doing, Thierry followed the Rule of St Benedict, which stated that the abbot should consult his entire flock before deciding on difficult issues and listen to their advice. Even concerning less important issues, the abbot was expected to consult the senior monks, if not the entire community. ${ }^{66}$ Thus in emphasizing Berenger's lack of communication, the Cantatorium put the responsibility for the reconciliation solely on Berenger's shoulders.

The Cantatorium does not recount how Berenger's monks reacted to the news of their abbot's reconciliation with Otbert. It can hardly be assumed that all of the monks embraced the news wholeheartedly, since they had been unwilling even to talk to Thierry II when he had "polluted" himself through mere negotiations with Otbert. Two of St. Laurent's monks had never forgiven Thierry for that, and they must have been equally unwilling to forgive their abbot for reaching a compromise with Otbert and giving him the kiss of peace. Even Rupert of Deutz, who had always been a great supporter of Berenger, would stubbornly refuse to be ordained by Otbert for many years to come and bitterly complained about prelates who flattered rather than reproached their patrons in order to preserve material benefits. ${ }^{67}$ A common complaint against Berenger seems to have been that he had acted out of personal ambition rather than a desire to serve the common good. ${ }^{68}$ To sum up, Berenger resumed his second abbacy at St. Laurent with a group of monks that may have been opposed to him, or at best deeply divided about his decision to return.

monks of St. Laurent, indicating that a part of Berenger's community supported his decision, whereas (as we shall see) others strongly opposed it.

${ }^{64}$ Cantatorium, $197-198$ (ch. 79).

${ }^{65}$ Ibid., 198 (ch. 80).

${ }^{66}$ Adalbert De Vogüé and Jean Neufville, eds., La règle de Saint-Benoît (Paris: Éditions du Cerf, 1972), 452-454 (ch. 3).

${ }^{67}$ De gloria et honore filii hominis super Mattheum, ed. H. Haacke, Corpus Christianorum Continuatio Mediaevalis 29 (Turnhout: Brepols, 1979), 381; see Van Engen, Rupert of Deutz, $38-42$.

${ }^{68} \mathrm{As}$ is clear from Berenger's defense in the Cantatorium, 198 (ch. 79). Much the same accusation was levelled against Lambert when he accepted the abbacy of Florennes, "victus cupiditate ambitionis," and Wired when he succeeded Thierry II in St. Hubert at the request of Otbert and Berenger, "nimis ambitioso et inconsiderate gloriam propriam querenti." Cantatorium, 165 and 227 (ch. 70 and 90). 
Lambert the Younger, who was very sympathetic towards Berenger as a person, complained that "many were amazed and even scandalized" when Berenger warmly embraced and kissed Otbert and was seated in the place of honor at the bishop's side ${ }^{69}$ This is a very strong choice of words. From Carolingian times until the mid-fourteenth century, a "scandalum" was defined as the act of committing a sin in front of another, causing that person to emulate the bad example and thereby leading him into ruin. ${ }^{70}$ Berenger's sin thus had severe consequences for his monks, who were forced to follow him because of their vow of obedience. Mayke de Jong has argued that the Carolingian world saw a scandalum as an insult to both God and the world at the same time, which made it a very serious offence. ${ }^{71}$ Scholars such as Lindsay Bryan and JeanMarie Moeglin have underlined that scandala retained their grave character throughout the High Middle Ages, when they were frequently listed as mortal sins. Eleventh- and twelfth-century authors, like their Carolingian predecessors, considered scandala as sins that could only be forgiven through some form of public repentance. ${ }^{72}$ This did not have to take the form of a strictly circumscribed ritual such as a formal deditio, but the penitent was explicitly required to satisfy the earthly and heavenly public that he had offended through an outward show of regret and various privations. ${ }^{73}$ Thus, when Lambert the Younger stated that many saw Berenger's actions as a scandalum, contemporaries would have understood that Berenger was accused of a severe sin that required public penance. This accusation could not be ignored. Both Berenger and his monks would have been aware of cases in which similar tensions had led monks to maim their abbot in order to get rid of him, and abbots to call on a bodyguard to protect themselves from their flock. ${ }^{74}$ To

\footnotetext{
${ }^{69}$ Cantatorium, 198 (ch. 79).

${ }^{70}$ Lindsay Bryan, "Vae mundo a scandalis": The Sin of Scandal in Medieval England $(\mathrm{PhD}$ dissertation, University of Toronto, 1998), ii, 38. This definition remained in place until the end of the fourteenth century, when "scandal" started referring to a person's individual reputation as a synonym of "shame," "disgrace," or "gossip."

${ }^{71}$ Mayke B. de Jong, The Penitential State: Authority and Atonement in the Age of Louis the Pious, 814-840 (Cambridge: Cambridge University Press, 2009), esp. 121, 152, and 232-238.

${ }^{72}$ Mayke B. de Jong, "Pollution, Penance and Sanctity: Ekkehard's Life of Iso of St Gall," in The Community, the Family and the Saint: Patterns of Power in Early Medieval Europe, eds. Joyce Hill and Mary Swan (Turnhout: Brepols, 1998), 149; Jean-Marie Moeglin, "Pénitence publique et amende honorable au Moyen Âge," Revue Historique 604 (1997): 234-235; and Bryan, "Vae mundo a scandalis." Sarah Hamilton, The Practice of Penance, 900-1050 (Suffolk, U.K.: Royal Historical Society: Boydell Press, 2001) has argued that public penance remained popular in this period, although its boundaries with more private forms of penance were muddied.

${ }^{73}$ Moeglin, "Pénitence publique," 235. It should be noted that this penance could very well be (semi-) voluntary, in contrast to the ritual of deditio (see Gert Althoff, "Das Privileg der 'deditio': Formen gütlicher Konfliktbeendigung in der mittelalterlichen Adelsgesellschaft," in Spielregeln der Politik im Mittelalter, ed. Gert Althoff (Darmstadt: Primus, 1997), 99-125).

${ }^{74}$ Famous examples from the region with which this paper is concerned can be can be found in Folcuin's Gesta or Deeds of the abbots of Lobbes, ed. Georg H. Pertz, MGH SS 4 (Hannover:
} 
prevent such incidents, both abbot and monks needed to express forgiveness and friendship and go through a repetitive cycle of rituals that would publicly bind them to a measure of tolerance vis-à-vis one another. Even though there are no sources that explicitly mention or describe such a reconciliation in the monastery of St. Laurent in 1095, it is likely that some reconciliatory initiative was nevertheless taken.

The obvious question at this point is why this presumed reconciliation was not discussed in contemporary sources. There are, in fact, three narrative sources that could have mentioned it. The first of these is a chronicle of the monastery's early years, the so-called Chronicon Sancti Laurentii Leodiensis. Even though it was written by the fifteenth-century Adriaan of Oudenbosch, it is consulted by scholars of the eleventh and twelfth centuries because Adriaan might have used a lost chronicle by Rupert of Deutz as his main source. ${ }^{75}$ Adriaan vividly describes how Berenger and Otbert reconciled, "not without the hate of many," and how this freed Berenger to return to St. Laurent. Adriaan ends his chronicle on this positive note, deliberately avoiding the years between 1095 and Berenger's death in 1116, during which the abbot and the bishop worked together quite amicably. ${ }^{76}$

The second narrative source dates from ca. 1160. It was written by Reinerus of St. Laurent, a monk who was examining the literary production of St. Laurent up to his own day. ${ }^{77}$ Of Berenger, Reinerus wrote only that he stemmed from a lower-class family and that the Lord had raised him free of the vile dust, lifted up his head, and exalted him to the amazement of the many (Ecclesiasticus/Sirach 11:12-13), whereupon he praised Berenger's virtues. He was pointedly silent about the conflict between Berenger, Wolbodon and Otbert, even though this conflict did lead to the production of Rupert of Deutz's Carmina, an incomplete literary gem. ${ }^{78}$ It can only be presumed that either Reinerus or his superiors did not deem it politic to recount the episode.

Impensis bibliopolii Hahniani, 1841), 68; and the Life of Poppo of Stavelot, ed. Georg H. Pertz, MGH SS 11 (Hannover : Impensis bibliopolii Hahniani, 1854), 303.

${ }^{75}$ Hubert Silvestre, Le "Chronicon Sancti Laurentii Leodiensis," dit de Rupert de Deutz (Louvain: Publications universitaires, 1952); John van Engen, "Rupert von Deutz und das sogenannte Chronicon sancti Laurentii Leodiensis: Zur Geschichte des Investiturstreites in Lüttich," Deutsches Archiv für Erforschung des Mittelalters 35 (1979), 33-81; Silvestre, "Rupert de Deutz a-t-il rédigé, au début de sa carrière, un recueil de réflexions pieuses sur l'histoire de l'abbaye liégeoise de St-Laurent?" Revue d'histoire ecclésiastique 77, no. 3-4 (1982): 365-395; idem, "Que nous apprend Renier de St. Laurent sur Rupert de Deutz?" Sacris Erudiri 25 (1982): 49-97.

${ }^{76}$ Chronicon, 279 (ch. 50).

${ }^{77}$ De ineptiis cuiusdam idiotae, 593-603.

${ }^{78}$ Carmina 622-641; Arduini, Non fabula sed res, 43-49. 
The third and most detailed description of the conflict is the Cantatorium, on which most of the above descriptions are based. It was written by Lambert the Younger, who was understandably gracious towards Berenger as the two men had enjoyed a close friendship as youths in St. Hubert. ${ }^{79}$ Perhaps Lambert was loath to describe how a conflict between Berenger and his own monks in St. Laurent caused his friend to lose face. More importantly, Berenger was again becoming a successful abbot at the time Lambert was writing his Cantatorium. St. Hubert was still deeply entangled in the battle between Otbert and Thierry II and needed all the supporters it could get. At the time when Lambert was writing the Cantalorium, Berenger was respected by Otbert as well as by Thierry and served as a mediator between the parties. ${ }^{80}$ It would have been distinctly unwise to antagonize Berenger and the worldly lords who had intervened for him and risk losing them as defenders of St. Hubert's interests. Such considerations, inconclusive as they are, may have played a role in keeping the details of the aftermath of Berenger's volte-face out of the Cantatorium.

Reading through these sources, it therefore remains frustratingly unclear how Berenger evolved from a scandalous abbot to a highly respected figure in a relatively short period of time. Why were the monks suddenly happy to accept Otbert and his new friend Berenger in their midst, given that they regarded communication with Otbert as an act of apostasy and had been afraid that admitting Thierry II to their priory would soil the purity of their faith? It seems unlikely that the monks of St. Laurent completely renounced their former views and joined Berenger's new regime without any lingering tensions.

However, it does not follow that those tensions must have sparked an outright conflict between Berenger and (a part of) his flock that was expertly covered up in the narrative sources. ${ }^{81}$ As we noted earlier, chronicles in general have a distinct tendency to concentrate on moments of conflict and the events of linear history. They rarely describe the day-to-day life of the

\footnotetext{
${ }^{79}$ Cantatorium, 96 (ch. 35); see Berlière, "Abbaye de Saint-Laurent," 37.

${ }^{80}$ For example, Otbert sends Berenger and the archdeacon Henry to St. Hubert to manage the abbey "as if it had no abbot," but Berenger returns to tell Otbert that Thierry II had returned to the abbacy (Cantatorium, 200 [ch. 81]). Somewhat later, both Thierry II and Otbert offer the abbacy of St. Hubert to Berenger, who refuses because the monks from St. Hubert are far from enthusiastic. Asked by Otbert to name someone else, Berenger suggests Wired, but also recommends that the monks of St. Hubert be consulted (Ibid., 213-215 [ch. 85-86]; also see 220-221 [ch. 89]). In this way, Berenger deftly navigates between the demands of Otbert and those of St. Hubert.

${ }^{81}$ As Martina Wiech (Das Amt des Abtes im Konflikt: Studien zu den Auseinandersetzungen um Äbte früh- und hochmittelalterlicher Klöster unter besonderer Berücksichtigung des Bodenseegebiets [Siegburg, Germany: Verlag F. Schmitt, 1999], 379) notes, conflicts between an abbot and his convent only appear in the sources when they became public knowledge through, for example, a complaint by one of the parties.
} 
monastery with its cycle of rituals. If the tensions between Berenger and his flock did not lead to drama but to a much more mundane process of repetitive steps towards virtue, mutual trust and acceptance, it would not have been considered suitable material for a chronicle.

At this point we should return to Brussels RL 9361-9367 (II). This manuscript was produced around the end of the eleventh century by a scribe from St. Laurent and explicitly discusses how holding monastic offices can endanger one's spiritual purity, while emphasizing the importance of penitence and humility. Perhaps this manuscript was used to soothe the tensions in St. Laurent. Could the congregation of St. Laurent have written Brussels RL 9361-9367 (II) in reaction to their return from exile? Could this manuscript have played a part in the reconciliation between abbot and flock?

\section{Between Berenger and Brussels RL 9361-9367 (II)}

If Brussels RL 9361-9367 (II) was connected to the return from exile, it was probably aimed at the person of Berenger. Wolbodon and Berenger were the only two dignitaries in eleventh- and twelfth-century St. Laurent whose prideful behavior was openly criticized. Yet the link between the abbacy of Wolbodon and the manuscript is not particularly strong, as nothing in the Cantatorium or other sources suggests that Wolbodon was ever persuaded to complete some kind of penance. During his first abbacy he actively refused to perform the penitence asked of him by the bishop, and during his second term the monks who were unhappy with his behavior simply fled to Berenger instead of forcing him to atone for his misdeeds. A stronger argument can be made for the relationship between Brussels RL 9361-9367 (II) and the abbacy of Berenger between 1095 and 1116.

First of all, it is noteworthy that the scribe chose to incorporate the still relatively obscure story of Theophilus into the codex, as it had some remarkable parallels to Berenger's situation. ${ }^{82}$ Both Theophilus and Berenger found themselves unjustly deposed from their positions by a bishop, and both were willing to treat with the devil and his henchmen-either literally or figuratively - to regain their posts.

Secondly, the link with Berenger's abbacy might explain why Brussels RL 9361-9367 (II) is concerned with the question of penance at home versus penance through exile, without ever fully resolving the issue. This reflects the very real concern with this question among the congregation of St. Laurent at the end of the eleventh century. When Berenger and his

\footnotetext{
${ }^{82}$ The Life of Theophilus would only become widely popular in this region during the twelfth century. See Gier, Der Sünder als Beispiel and BHLms, http://bhlms.fltr.ucl.ac.be.
} 
monks were living in exile, they consoled themselves that exile guaranteed their purity because it cut them off from the contamination of sin. As a result, the monks must have been concerned for their moral status when Berenger made them all return and communicate with Otbert. Could they possibly regain the moral perfection they had enjoyed in exile? Much depended on the answer, for if perfection at home was impossible, Berenger had indefensibly put his monks' souls in danger, but if perfection could be achieved in St. Laurent as well as in Evergnicourt, his decision to return might be defensible. The evidence suggests that the monks of St. Laurent were divided on this issue. As we saw, Rupert of Deutz complained that some monks renounced their old views and consented to come into contact with Otbert, whereas he himself stuck to the ideals of exile. The fifteenthcentury Chronicon equally suggested a rift between the monks. Brussels RL 9361-9367 (II) seems to reflect this rift and advocates penance in a coenobitic environment filled with whispering temptations, while simultaneously incorporating some texts that laud the virtues of exile.

Last but not least, the manuscript encourages penitence for the sin of pride, and a careful reading of the Cantatorium reveals that contemporaries explicitly accused Berenger of pride, ambition, apostasy, and probably a lack of consultation. His reconciliation to Otbert was much disputed and caused a scandalum, a choice of words implying that Berenger was obliged to atone by means of a public penance. ${ }^{83}$ It should be noted that such a public penance not only imposed a certain type of behavior on the sinner, but also drew the participants into the rituals. There is an obvious parallel here with secular society, where appealing to juridical or other formalized means was not usually enough to truly end a conflict. The participants also had to go through a repetitive series of encoded modes of behavior that expressed both parties' willingness to reconcile. ${ }^{84}$ This fits with the contents of Brussels RL 9361-9367 (II). It focuses on prideful officeholders who are in dire need of penitence, exhorts them to bewail their sins in public, and frames this demand as an instance of (semi-) voluntary penance.

The hypothesis that Brussels RL 9361-9367 (II) functioned in a penitential context is strengthened by its layout, which strongly suggests that the codex was read aloud in front of the monastic community. The first thing to note here is that the opening books of the Synonyma and De conflictu are laid out in a way that is reminiscent of a theatrical setting. For example, the transcription below represents the first folio of the manuscript where the dialogue between Reason (ratio) and the Soul (anima) begins:

\footnotetext{
${ }^{83}$ Moeglin, "Pénitence publique," 234.

${ }^{84} \mathrm{Cf}$. infra.
} 
Incipit liber sancti Ysidori de conflictu rationis et animae.

Ratio.

Deus tibi, [ó anima], optata retribuat, Deus uotis tuis faueat, [...] dilui solent.

ANIMA.

Heu mihi infelix anima! In tantis peccatis,

[. . .] quod exsuperat omnia mala .

Ratio.

Heu anima! Quid est quod multo [amplius] metuis?

[...] [me]tuis?

ANIMA.

Metuo diem iudicii, metuo diem tenebrarum, diem amarum, diem durum. Perpen[do]

The lines of Ratio and Anima always start with a red initial. Moreover, the scribe executed the rubrics "Ratio" and "ANIMA" in red ink and placed them in the right margin, directly above the start of the lines that were spoken by Reason and Soul. ${ }^{85}$ In doing so, he consistently indicated the two speakers of the dialogue before their lines actually started, which enabled one speaker to step away from the codex to make room for another speaker or to pass the codex to someone else at the appropriate moment. Furthermore, the scribe explicitly named the character "Anima" in the opening sentence of the codex, so that an audience, which could not read the rubrics because it was listening to the dialogue would nevertheless understand right from the start that a Soul was speaking to some kind of counselor. The scribe accomplished this by inserting the words "O Soul" into the first line spoken by Reason, changing "Deus tibi optata retribuat" to "Deus tibi, ó anima, optata retribuat." The Soul then answers "Heu mihi infelix anima! In tantis peccatis," and Reason responds "Heu anima! Quid est," thereby clearly establishing the alternation between the two speakers. A similar layout is used in De conflictu. Again the speakers are identified in red rubrics, in the right margin, before the first line of their text. The scribe made sure that the rubrics always started above the lines spoken by each particular character, even though this often forced him to split the rubrics over two lines ("Superbia namque / dicit," "Sed / vera humilitas respondet," etc.):

et diaboli collisa decertent. Superbia namque

Certe multis, imo etiam pene omnibus dicit.

[...] [cunc]tis temet ipsum superiorem attende. Sed

Memento vera humilitas respondet

quia pulvis es, quia cinis es, quia putredo

[...] in aliquo debet humana infirmitas? Inanis

Age bonum quod vales, < gloria dicit.

\footnotetext{
${ }^{85} \mathrm{He}$ twice diverged from this pattern by mistake (fols. $89 \mathrm{v}$ and $90 \mathrm{r}$ ). This, incidentally, indicates that he was copying a manuscript that was not laid out in a similar semi-theatrical manner.
} 
ostende cunctis bonum quod agis, ut bonus

[. . .] debitum tibi honorem persolvant. Sed timor

Si quid boni aliquid < domini respondet

agis, non pro transitoriis sed pro aeternis honoribus age. ${ }^{86}$

Occasional accents on words that are easily garbled when spoken aloud are another indication that the codex was not read silently. For example, the mispronunciation of "tenère" as "tēnere" is avoided on fol. 90v by an acute accent ("Cave autem honores quos tenére sine culpa non potes"), and many similar examples can be cited. ${ }^{87}$ For an individual reader, such accents are as unnecessary as the conspicuous layout and the clear indication of the speakers in the dialogue. To borrow a phrase from Graham Runnalls, the layout and accents gave these texts the "para-dramatic potential" to be "in some sense performed." Indeed, Symes has argued that this was a time when worship and drama were not yet clearly separable, and that the early play can often be recognized by its clear indication of the speakers-more detailed instructions for performance only became common in the fourteenth century. ${ }^{88}$ It was usual that codices combined play-like texts with ostensibly non-dramatic texts, such as the saints' lives in Brussels RL 9361-9367 (II), which do not have similar rubrics to indicate the speakers. Although hagiographical texts were often read aloud, it was not usually done in a theatrical manner that required distinctive rubrication. ${ }^{89}$ All in all, the texts in the codex were remarkably suitable for reading aloud because of their genre, the accents, the clear indication of speakers, and the layout of the rubrication. This indicates that Brussels RL 9361-9367 (II) was meant not to be perused by one person at a time, but to be read or even performed in front of St. Laurent's monastic community.

The manuscript might have been read in its entirety in one sitting, but there are certain indications that the readings were spread out over the days of the liturgical week. First of all, the manuscript is far longer than the average

\footnotetext{
${ }^{86}$ Brussels RL 9361-9367, fol. 91r-v.

${ }^{87}$ Other examples of words with acute accents are "ó anima" and "formído" on fol. 89r, "cónficis" and "éxcidit" on fol. 93r, "reláberis" on fol. 93v, "domolíta" on 103v, "invenítur" on fols. 89 r, $89 \mathrm{v}, 92 \mathrm{v}$, and so forth.

${ }^{88}$ Carol Symes, "The Appearance of Early Vernacular Plays: Forms, Functions, and the Future of Medieval Theater," Speculum 77, vol. 3 (2002), esp. 825, 829-830, contains the quote from Runnalls. Symes notes the irony that texts which were carefully provided with rubrics to facilitate performance are usually dismissed as didactic or "semi-theatrical." She also notes that (vernacular) plays before 1300 are always presented as "organic to their manuscript surroundings, suggesting in turn that drama was not categorically removed from worship or daily life" (794). See also Norma Kroll, "Power and Conflict in Medieval Ritual and Plays: The Re-Invention of Drama," Studies in Philology 102, no. 4 (2005): 466-473.

${ }^{89}$ Guy Philippart, Les légendiers latins et autres manuscrits hagiographiques (Turnhout: Brepols, 1977), 112-118.
} 
sermon or reading, ${ }^{90}$ and the texts are not ordered in the format of a classical penitential story. This is to say that this is not a codex in which the first text dwells on guilt, the middle texts on penitence, and the last texts on reconciliation, in order to figuratively take the community by the hand and lead it from conflict to peacefulness. Instead, the texts are ordered according to their auctoritas. The codex opens with Isidore of Seville, continues with the treatise De conflictu (the author of which was unknown to the scribe of Brussels RL 9361-9367 (II)), and ends with the far less prestigious saints' lives. As a result, the codex obviously was not meant to be read as a whole in one sitting. Instead, it was probably used like most monastic texts and read in smaller fragments, perhaps one text per day of the week. In that way the readings would emphasize the repetitive nature of the penance. This was important because it allowed the monks to grasp the spiritual meaning of the texts, as Hugh of St. Victor argued. Furthermore, Sonntag has pointed out that it was not easy to achieve true closure of a deep rift between an abbot and his monks while simultaneously maintaining the abbot's authority over his congregation. ${ }^{91}$ A single ceremony, strictly regulated and adhering to the hierarchical rules of Benedictine life, would not by itself have the desired effect, as monks tended to be fearful of dissimulation on the part of the sinner, who might try to reconcile without truly feeling the error of his ways. ${ }^{92}$ Monks were normally unwilling to forgive grave errors immediately. Instead, they required a period of ritual separation of the sinner from the community, giving both parties the chance to come to terms with the idea of forgiveness and true reconciliation. Therefore, repeated penitential readings could serve as small steps in a much longer process of reintegration, interspersed with cleansing rituals that were often similar to secular practices. ${ }^{93}$ If this is how the St. Laurent codex was used, chroniclers would not have considered such a reconciliation as suitable material for their narratives. At best, they would have mentioned an end result, such as the renewed vigor of the St. Laurent community, but the precise format of the reconciliation was likely to have remained a part of oral culture.

During what time of the liturgical day could Brussels RL 9361-9367 (II) have been used? There were four daily occasions for public reading: the celebration of Mass and the offices, mealtimes in the refectory, and Chapter

\footnotetext{
${ }^{90}$ Tjamke Snijders, "Celebrating with Dignity: The Purpose of Benedictine Matins Readings," in Understanding Monastic Practices of Oral Communication (Western Europe, Tenth-Thirteenth Centuries), ed. Steven Vanderputten (Turnhout: Brepols, 2011), 121.

${ }^{91}$ Sonntag, Klosterleben, 388-389.

${ }^{92}$ Ibid., 375; Hamilton, "Penance," 54-56.

${ }^{93}$ See for example the Redactio Fuldensis-Trevirensis in Corpus Consuetudinum Monasticarum, eds. Maria Wegener, Candida Elvert and Kassius Hallinger, vol. VII, no. 3, Consuetudinum saeculi X/XI/XII, monumenta non-Cluniacensia (Siegburg: Franciscum Schmitt success, 1984), 280 (VI, 17); also Sonntag, Klosterleben, 413 and 419-420.
} 
meetings. ${ }^{94}$ It is unlikely that the codex was read in Mass, or during the offices. None of the texts show the common markers of liturgical use, such as marginal signs that indicated where readings were to start and end, or any indications about the day on which these texts were to be read. ${ }^{95}$ This is not surprising, as it would have been difficult to integrate this manuscript into the rigorously structured liturgical services with their highly formalized readings.

The codex could certainly have been read during mealtimes. Monks were accustomed to eat while listening to hagiographical and spiritual readings much like the ones in Brussels RL 9361-9367 (II). In the Flemish monastery of Anchin, for instance, the thirteenth-century refectory readings comprised the lives of saints together with spiritual work from authors such as Bernard of Clairvaux, Gregory the Great, and Cassiodorus, as well as Isidore's Synonyma. ${ }^{96}$

However, the codex would have been particularly well suited to the Chapter meetings that usually followed prime. ${ }^{97}$ The principal function of a Chapter meeting was to give monks an opportunity to discuss important problems that pertained to the community as a whole, to formally accuse one another of misdeeds, and to atone for them through proper penitence. Under normal circumstances, the abbot occupied center stage during these meetings. ${ }^{98}$ When monks accused one another he would lead or at least supervise the interrogation of the accused, decide on proper punishments, and admonish the monastic community with a sermon. ${ }^{99}$

If an abbot was accused of misdeeds during Chapter and had to become a penitent, he was not allowed to actively participate in the liturgy, although he was expected to continue the administrative and representative duties that were crucial to the community's survival. In particular, the abbot had to abstain from giving any form of sermon, reading, or other formal admonition to his monks. ${ }^{100}$ As long as the abbot was penitent, one of the community's other priests had to take over these important tasks. If we proceed from the hypothesis that Berenger was required to perform some kind of penitence for his scandalum, a priest would have replaced him during Chapter meetings to

\footnotetext{
${ }^{94}$ Andrew Hughes, Medieval Manuscripts for Mass and Office: A Guide to their Organization and Terminology (Toronto: University of Toronto Press, 1982), 14-20; Hamilton, The Practice, 86.

${ }^{95}$ A. G. Martimort, Les lectures liturgiques et leurs livres (Turnhout: Brepols, 1992), 100-101.

${ }^{96}$ Nebbiae-Dalla Guarda, "Les listes," 283-288.

${ }^{97}$ Hughes, Medieval Manuscripts, 18.

${ }^{98}$ Sonntag, Klosterleben, 399-419.

${ }^{99}$ Lanfranc suggests that a designated lector took care of the first readings, but that the abbot himself gave the sermon (The Monastic Constitutions of Lanfranc, ed. David Knowles and Christopher N. L. Brooke (Oxford: Oxford University Press, 2002), 164n370. See also the Life of Benedict of Aniane, ed. Georg Waitz, MGH SS 15 (Hannover: Impensis bibliopolii Hahniani, 1887), at 216-217; and the meetings described in the Cantatorium, 173 (ch. 72 ), 178 (ch. 73 and 75), 199 (ch. 80), 226 (ch. 89).

${ }^{100}$ Sonntag, Klosterleben, $440-442$.
} 
give the traditional readings and sermons. It stands to reason that a great deal of thought would have gone into the selection of fitting material for those occasions. The readings would need to guide Berenger and his community through the unfamiliar and presumably uncomfortable situation. Brussels RL 9361-9367 (II), which can be interpreted as treating St. Laurent's situation through veiled and prudent language, would have been a perfect fit.

It would assuredly have been a humiliating experience for Berenger to sit in the refectory or in Chapter and listen to readings from Brussels RL 9361-9367 (II) that encouraged the abbey's highest officeholders to bewail their sins, detailed the dangers of pride and ambition in office, discussed the virtue of true humility, and discreetly touched on the question of moral perfection through exile. Nevertheless, his penance would almost certainly have benefited him in the long run. The effect of penitence in general could be positive as long as it was undertaken voluntarily. As Mayke de Jong recently argued, only enforced penance was seen as shameful, whereas a sinner who freely and sincerely confessed his guilt kept the initiative, and thereby his honor. ${ }^{101}$ A voluntary penitent would usually gain prestige and power because of his penance. In Brussels RL 9361-9367 (II), this mechanism is exemplified in the story of Theophilus, whose voluntary penance not only saved his soul from the devil but even turned the sinner into a saint. This notion of empowerment through penance was so common that injured parties sometimes refused to let a culprit take the penitential initiative in order to prevent this very effect. ${ }^{102}$ This was not a problem in St. Laurent, as the texts in Brussels RL 9361-9367 (II) suggest that its community was quite amenable to framing Berenger's penitence as voluntary. As we saw, the opening lines of the codex succinctly encourage the Soul to confess, whereupon he bursts out in profuse lamentations of guilt and sorrow over his misdeeds. The Synonyma was a textbook example of voluntary penance, just like the Lives of Theophilus and Mary of Egypt. If these texts were read with Berenger in attendance, they would have framed his sin in such a way that the abbot could take full responsibility for his decision to return to St. Laurent, take all the related sins upon himself, do voluntary penance for them, and thus start to reconcile with his flock. De conflictu and the Lives of Euphrosyna and Paula sketched the life of exemplary humility that all monks should aspire to, and De conflictu also provided the practical tools to achieve such a virtuous life. The result is a discourse that could serve to restore the abbot's authority, thanks to his heroic penitential attitude and his wish to better himself. An illuminating parallel can be drawn between this discourse and the penitence of Louis the Pious in 822 and 833. Like Berenger, Louis

\footnotetext{
${ }^{101}$ De Jong, The Penitential State, 231.

${ }^{102}$ For example, ibid., 269.
} 
was seen as someone who had sinned in his capacity as a ruler over others. ${ }^{103}$ He had explicitly fashioned himself as the "abbot" of his realm yet had failed to guard the equitable right order of his dominion, as was expected of an abbot. ${ }^{104}$ His multiple penances over the years to atone for his sins were successful inasmuch as they were perceived as both sincere and voluntary.

Even if Berenger was the first to benefit from these rituals, they also would have been a form of collective cleansing for the community as a whole. The ideas of collective penance and fraternal penitential assistance through admonition and punishment were central to monastic life. ${ }^{105}$ Around the same time, a scribe from the abbey of St. Bertin in Flanders was also looking to consolidate modes of reconciliation between the reformist Abbot Lambert (1095-1123) and his monks. In a story that he projected upon the previous reform of the monastery in the early eleventh century, the monks refused to accept the abbot's authority until the hand of God struck them with several disasters, including a fire in the monastery and an epidemic. Desperate for their lives, the monks turned to the abbot, who recommended an act of collective penance and then moved on to introduce reform. ${ }^{106}$ This collective element seems key to Brussels RL 9361-9367 (II) as well. If our hypothesis is correct, the manuscript put the abbot at the forefront, yet simultaneously emphasized that he could indeed be forgiven. It would have consoled the monks by suggesting that they could achieve perfection in St. Laurent as well as in Evergnicourt if they kept to Ambrose Autpert's precepts, thereby removing one reason for their resentment and encouraging them to practice the virtue of humility. In this light, the scribe of Brussels RL 9361-9367 (II) probably attempted to recreate solidarity within the monastic community through a manuscript that could facilitate a long-term process of shared catharsis, involving both the monks and the abbot of St. Laurent.

It is unclear how common it was for manuscripts to be used this way. On the one hand, it was quite usual for monastic communities to produce a manuscript in response to a particular crisis within the monastery. For example, the community of St. Amand in Flanders reacted to the burning of their abbey with the creation of a very luxurious manuscript that centered around the deeds of their patron saint, in order to ostentatiously promote the continued

\footnotetext{
${ }^{103}$ Ibid., 240-241; see also Courtney M. Booker, Past Convictions: The Penance of Louis the Pious and the Decline of the Carolingians (Philadelphia: University of Pennsylvania Press, 2009), esp. 146-149.

${ }^{104}$ Booker, Past Convictions, 224-229.

${ }^{105}$ Rapp, "Spiritual Guarantors at Penance," 144-145.

${ }^{106}$ Simon of Ghent, Gesta abbatum Sithiensium, ed. Oswald Holder-Egger, MGH SS 13 (Hannover 1881), 636-637; see Steven Vanderputten, "Individual Experience, Collective Remembrance, and the Politics of Monastic Reform in High Medieval Flanders," Early Medieval Europe 20 (2012): 70-89.
} 
might and wealth of St. Amand. ${ }^{107}$ The monastery of St. Hubert reacted to the difficulties with bishop Otbert by producing an aggressively Gregorian manuscript that contained texts such as the donation of Constantine, "Opinions of various Fathers on the primacy of the Roman Church," and writings by Gregory VII. ${ }^{108}$ The idea of manuscript performativity during fraught periods was clearly widespread. On the other hand, there are hardly any studies of manuscripts with a clear penitential function in the wake of a conflict, as historians who study conflict often overlook the (semi-)liturgical manuscripts, whereas liturgists often hesitate to connect their manuscripts to historical conflicts. However, there are a good number of extant manuscripts that contain penitential texts such as Isidore's Synonyma or the Lives of penitential saints such as Mary of Egypt, Mary Magdalene, Thaïs or Pelagia. Some of these manuscripts are similar to Brussels RL 9361-9367 (II) in that they combine a few obviously penitentiary texts with seemingly miscellaneous material. In a late thirteenth-century manuscript from St. Jacques in Liège, for example, the Synonyma was combined with a "modus confitandi," Thomas Aquinas's De fallaciis, texts from Hugh of St. Victor, songs, and prayers. ${ }^{109}$ A manuscript from Parc Abbey combined the Synonyma with extracts from "de humilitate et superbia" and Hugh of St. Victor's De confessione as well as "flores epistolarum Hieronymi et Augustini." 110 When examined in greater detail, such seemingly miscellaneous manuscripts are likely to reveal a performative function similar to that of Brussels RL 9361-9367 (II).

\section{CONCLUSION}

This article has examined a late eleventh-century manuscript that stands out from others in the St. Laurent library because of its curious selection of seemingly miscellaneous texts. Not only does it run counter to the monks' general practice of avoiding doubles in their library, but the combination of texts is also unusual in itself. Its creation was clearly inspired by the interrelated themes of the monastic exercise of power, the sins that stem from it, and the spiritual restoration that can be achieved through penance. We have argued that the manuscript seems linked to the political upheaval that resulted from the community's exile to Evergnicourt by Bishop Otbert of Liège between 1092 and 1095, and show how the combination of texts in

\footnotetext{
${ }^{107}$ Valenciennes BM 502. See Barbara Abou-El-Haj, The Medieval Cult of Saints: Formations and Transformations (Cambridge: Cambridge University Press, 1994), 62-63.

${ }^{108}$ Namur, Musée des Arts anciens, 5.

${ }^{109}$ Darmstadt, Universitäts- und Landesbibliothek, 2777.

${ }^{110}$ Brussels RL 21860.
} 
this manuscript takes on a different meaning because of these politically charged circumstances.

When Abbot Berenger suddenly reconciled with his nemesis without first consulting his monks, he caused a scandalum, even in the eyes of his close friend Lambert. By its very nature a scandalum required public penance, and the St. Laurent monks tended to be unfavorably disposed towards people who negotiated with Otbert. As a result, there must have been a rift between Berenger and a significant number of his monks, if not the entire community. Yet no contemporary author describes Berenger's penance and the reconciliation that must, by necessity, have followed.

Reconciliations such as these can either be viewed as a strictly monastic affair (as Steffen Patzold has argued) or as a moment of conflict resolution that was handled not very differently from those in secular society. ${ }^{111}$ Scholars such as Gert Althoff, Patrick Geary, and Stephen White have argued that the elite cultures of the monastery resembled those of the secular world to such an extent that similar approaches were indeed quite probable. Conflict resolution, in their view, should be understood as a complex set of behavior patterns that served to reveal both parties' wish to manage the conflict in a controlled manner. ${ }^{112}$ Instead of resolving the conflict in one large meeting, a true resolution took enough time so that all parties could grow convinced of the other's veracity. Sonntag has argued that similar concerns about the opposition's reliability were very much present in the monastery, where forgiveness was rarely instantaneous, and Hugh of St. Victor explained that monastic discipline and penance had to be practiced in a repetitive cycle for monks to understand the true virtue of their actions. Drawing these arguments together, we propose that the apparently miscellaneous Brussels RL 9361-9367 (II) contains readings that fit this concept of conflict resolution through long-term penitential rituals. The

\footnotetext{
${ }^{111}$ See Patzold, Konflikte.

${ }^{112}$ Warren C. Brown and Piotr Górecki, "What Conflict Means: The Making of Medieval Conflict Studies in the United States, 1970-2000," in Conflict in Medieval Europe: Changing Perspectives on Society and Culture, eds. Warren Curtis Brown and Piotr Górecki (Aldershot, U.K.: Ashgate, 2003), 1-35; and by the same authors, "Where Conflict Leads: On the Present and Future of Medieval Conflict Studies in the United States," in Conflict in Medieval Europe, 265-285. For further reading, see, among many others, Stephen D. White, "From Peace to Power: The Study of Disputes in Medieval France," Medieval Transformations: Texts, Power, and Gifts in Context, eds. Esther Cohen and Mayke B. de Jong (Leiden, Netherlands, Brill, 2001), 203-218, reprinted in Feuding and Peace-Making in Eleventh-Century France (Aldershot, U.K.: Ashgate, 2005), 1-14 (article 8); Patrick Geary, "Moral Obligations and Peer Pressure: Conflict Resolution in the Medieval Aristocracy," in Georges Duby: L'écriture de l'histoire, eds. Claudie Duhamel-Amado and Guy Lobrichon (Brussels: De Boeck Université, 1996), 217-222; and Steven Vanderputten, "Monks, Knights, and the Enactment of Competing Social Realities in Eleventh- and Early-Twelfth-Century Flanders," Speculum 84, no. 3 (2009): $582-612$.
} 
codex can be understood as an instrument to slowly reconcile Berenger with his monks, thereby avoiding open conflict and keeping the tensions out of contemporary narrative sources.

Several parts of Brussels RL 9361-9367 (II) were clearly read aloud in front of a monastic audience, probably in the refectory or during Chapter meetings. The manuscript may have been used instead of Berenger's traditional sermon in Chapter throughout the period of his presumed penance, especially because the manuscript presented its protagonists as voluntary penitents. In this interpretation, the texts of Brussels RL 9361-9367 (II) would have provided Berenger with a platform to present himself as a penitent without losing face or abbatial authority. For the monks, the manuscript contained an admission of abbatial guilt as well as a tacit assurance that their own spiritual welfare had not been compromised, while simultaneously encouraging them to forgive the penitent sinner. The manuscript could thus be used to encourage the community as a whole to re-establish the traditional monastic hierarchy as set forth by Benedict's Rule. As a result, Brussels RL 9361-9367 (II) provided both parties with the means to rebuild mutual trust and, in due course, to become truly reconciled. 